\title{
C BUDGET IN THE AGROECOSYSTEMS OF MAIZE (ZEA MAYS L.) AND RAPESEED (BRASSICA NAPUS L.)
}

\author{
Ovidijus MIKŠA, Institute of Environment and Ecology, Aleksandras Stulginskis University, Studentų g. 11, LT-53361, \\ Akademija, Kaunas raj., Lithuania; manomiskas@info.lt \\ Ligita BALEŽENTIENĖ, Institute of Environment and Ecology, Aleksandras Stulginskis University, Studentu g. 11, LT-53361, \\ Akademija, Kaunas raj., Lithuania, ligita.balezentiene@asu.lt (corresponding author)
}

The aim of this research was to calculate and compare the $\mathrm{C}$ budget changes for maize (Zea mays L.) and rapeseed (Brassica napus L.), identifying soil seasonal respiratory $\mathrm{CO}_{2}\left(\mathrm{R}_{\mathrm{a}+\mathrm{h}}\right)$ and assimilated photosynthetic $\mathrm{CO}_{2}$ at plant different growth stages. The research was carried out for maize (Zea mays L.) and rapeseed (Brassica napus L.), during the vegetation period (2014 June - September) at the PI ASU Training Farm, Kaunas district. The mean soil $\mathrm{CO}_{2}$ emissions were $1.971 \pm 0.12 \mu \mathrm{mol} \mathrm{m}^{-2} \mathrm{~s}^{-1}$ for maize, and $2.199 \pm 0.25 \mu \mathrm{mol} \mathrm{m} \mathrm{s}^{-1}$ for rapeseed. The highest measured soil $\mathrm{CO}_{2}$ emissions $2.432 \pm 0.23 \mu \mathrm{mol} \mathrm{m}^{-2} \mathrm{~s}^{-1}$ for rapeseed in June, and 2. $963 \pm 0.28 \mu \mathrm{mol} \mathrm{m}{ }^{-2} \mathrm{~s}^{-1}$ for the maize in the second half of July. The mean C budget in maize agro-ecosystems was $15.54 \mathrm{t}$ ha ${ }^{-1}$, while it was $10.30 \mathrm{t} \mathrm{ha}^{-1}$ in rapeseed.

Keywords: Brassica napus, $\mathrm{CO}_{2}$ emissions, Zea mays.

\section{INTRODUCTION}

At present, researchers and politicians identify the climate change as important threat and challenge for mankind (IPCC, 2007). Carbon dioxide $\left(\mathrm{CO}_{2}\right)$ is a long-living greenhouse gas that contributes to climate change. Therefore carbon capture and sequestration has been identified as a way to mitigate $\mathrm{CO}_{2}$ emissions to the atmosphere. Agricultural lands generate large $\mathrm{CO}_{2}$ fluxes both to and from the atmosphere (Schimel et al., 2002). Nonetheless, agroecosystems indicate the potential of sequestering carbon as an option for climate change mitigation (Aertsens et al., 2013). $\mathrm{CO}_{2}$ production depends strongly on many environmental (temperature, moisture, organic content in soil) and biological issues (above ground canopy size, growth activity, etc). Formation of carbon pool in soil depends on the inputs (with the plant residues and organic fertilizers) and taken away (with taken yield, mineralization, etc.) of organic C amounts of agroecosystems (Robert, Saugier, 2003). Extensive research in carbon budget is carried out in maize and soybeans agroecosystems (Hollinger et al., 2005; Pattee et al., 2002; Suyker et al., 2005) as well as rice (Saito et al., 2006) and winter wheat (Anthoni et al ., 2004). However, all assessments are inherent from soil as soil respiration. These emissions from the soil into the atmosphere create the major part (60-90\%) of the global C-cycle (Liang, Fang, 2004). Nowadays 12-15\%, or 5.1-6.1 Gt CO $\mathrm{CO}_{2 \mathrm{ek} .} \mathrm{m}^{-1}$ of the global greenhouse gas emissions are generated in agriculture (9\% of the EU) (IPCC, 2007). $1.6 \pm 0.8 \mathrm{Pg} \mathrm{C}$ per year (Schimel et al., 2002) is emitted into the atmosphere due to deforestation and land use change causing the transformation of the soil physical, agrochemical and biological properties (Weisskopf et al., 2010). Weather conditions also have a significant impact on $\mathrm{CO}_{2}$ emissions (Baležentienè , Kusta, 2012) and photosynthesis processes (Root et al., 2003). It was found that emitted $\mathrm{CO}_{2}$ rate vary during the vegetation season (June - September), and is strongly correlated with temperature and humidity $(r=0.7)$ in agro-ecosystems (Baležentienè, Bleizgys, 2011). It is affirmed that different tillage, agricultural systems (intensive, organic, etc.) and autotroph species altered metabolism and thus $\mathrm{CO}_{2}$ emissions in the system soil - autotrophs - atmosphere (Smith, 2008).

Carbon budget in agroecosystems is characterized by a net primary production (NPP), which defines C rates assimilated and accumulated in the autotroph biomass, or a net ecosystem exchange (NEE) (Anthony, Connolly, 2004). It might be considered as $\mathrm{C}$ amount sequestered by ecosystem and has been identified as a way to mitigate $\mathrm{CO}_{2}$ emissions to the atmosphere. $\mathrm{C}$ budget can be calculated by measuring the autotrophic and heterotrophic respiration flows in different agro-ecosystems (Baldocchi, 2003). In the Baltic countries, including Lithuania, there is no practically applicable appropriate data on $\mathrm{C}$ budget in agroecosystems.

Recent investigation have analyzed the seasonal carbon budget (sequestration and $\mathrm{CO}_{2}$ emissions) in crop ecosystems. The emphasis is on seasonal changes and different agroecosystems. The main aim of the research was to evaluate and compare the $\mathrm{C}$ budget in terms of $\mathrm{CO}_{2}$ assimilation capacity due to photosynthesis and $\mathrm{CO}_{2}$ emissions during seasonal respiration at different crop growth stages for maize (Zea mays L.) and rapeseed (Brassica napus L.) ecosystems.

Copyright (C) 2015 The Authors. Published by Aleksandras Stulginskis University. This is an open-access article distributed under the terms of the Creative Commons Attribution License (CC-BY 4.0), which permits unrestricted use, distribution, and reproduction in any medium, provided the original author and source are credited. 


\section{MATERIALS AND METHODS}

The research on $\mathrm{C}$ budget in maize (Zea mays L.) and rapeseed (Brassica napus L.) agroecosystems was conducted in 2014 during the vegetation season (June - September) at PI ASU training farm (local coordinates $54^{\circ} 52^{\prime} \mathrm{N}, 23^{\circ} 49^{\prime} \mathrm{E}$ ), Kaunas district. Cropland soil-common shallow luvisol (Hapli-Epihypogleyic Luvisol, LVG-PW$h a$, or moraine loamy podzolized shallow luvisol (Albi-Epihypogleyic Luvisol, LVG-pw-AB) (Lithuanian ..., 2001).

For the $\mathrm{C}$ metabolism studies, research bars were arranged in the agroecosystem fields in linear transects, oriented in the north - south direction, 20-25 m from the edge of the field, in order to avoid the edge effect. The research bars were randomly distributed on the transects every 50-100 m. Research sites were located on the transect sites in 6 replications. Plastic rings (wall thickness $-3 \mathrm{~mm}$, length $-5 \mathrm{~cm}$, diameter $-11 \mathrm{~cm}$ ) were installed at $2-5 \mathrm{~cm}$ depth of soil arable layer.

For the evaluation of $\mathrm{C}$ budget, the gross primary production (GPP, $\mu \mathrm{m}^{-2} \mathrm{~s}^{-1}$ ), respiration (R) and agroecosystem net primary production (NPP) for each crop agroecosystem were estimated and described by equation (Amthor, Baldocchi, 2001):

$$
\mathrm{NPP}=\mathrm{GPP}-\mathrm{R}_{\mathrm{a}+\mathrm{h}}
$$

$\mathrm{CO}_{2}$ emissions and assimilated photosynthetic $\mathrm{CO}_{2}$ flux intensity of plants (autotrophs) were measured by a static close-chamber method using the system LCpro (ADC Bioscientific LTD, UK). Autotroph' respiratory $\mathrm{CO}_{2}$ emissions $\left(R_{a}\right)$ were measured in the dark. Measurements of soil (autotrophs and heterotrophs) respiration $\left(R_{a+h}\right)$ and photosynthesis $\mathrm{CO}_{2}$ fluxes were carried out every 7-10 days in dependence on the meteorological conditions at different plant growth stages in BBCH scale (Meier, 2001).

To evaluate photosynthetic assimilation area, the leaf surface area of $0.25 \mathrm{~m}^{-2}(0.5 \mathrm{~m} \mathrm{x} 0.5 \mathrm{~m})$ at 6 replications was scanned using the device WinDias $3\left(\mathrm{~cm}^{2} \mathrm{~m}^{-2}\right)$ for the calculation of the leaf surface index (LAI, $\left.\mathrm{m}^{2} \mathrm{~m}^{-2}\right)$. For the evaluation of crop productivity the crude biomass $\left(\mathrm{g} \mathrm{m}^{-2}\right)$ has been measured by weighing method at different growth stages.

Using cylindrical auger were taken soil samples for the joint agrochemical analysis (ISO10381-2: 2002), which was carried out in the Agrochemical Research Centre laboratory of Lithuanian Research Centre of Agriculture and Forestry. The following soil agrochemical parameters were assessed: organic $\left(\mathrm{C}_{\mathrm{org}}\right)$ and total carbon concentration $\left(\mathrm{C}_{\text {total }}\right)$, total nitrogen concentration $\left(\mathrm{N}_{\text {total }}\right), \mathrm{PH}, \mathrm{P}_{2} \mathrm{O}_{5}$ and $\mathrm{K}_{2} \mathrm{O}$ concentrations and electrical conductivity (EL) (table1).

Table 1. Soil agrochemical parameters and electrical conductivity

\begin{tabular}{|l|c|c|c|c|c|c|c|}
\hline Agroecosystem & $\begin{array}{c}\text { Corg., } \\
\%\end{array}$ & $\begin{array}{c}\text { Cotal, } \\
\%\end{array}$ & $\begin{array}{c}\mathrm{N}_{\text {total, }} \\
\%\end{array}$ & $\mathrm{pH}$ & $\begin{array}{c}\mathrm{P}_{2} \mathrm{O}_{5}, \\
\mathrm{mg} \mathrm{kg}^{-1}\end{array}$ & $\begin{array}{c}\mathrm{K}_{2} \mathrm{O}, \\
\mathrm{mg} \mathrm{kg}^{-1}\end{array}$ & $\begin{array}{c}\mathrm{EL}, \\
\mathrm{mS} \mathrm{m}^{-1}\end{array}$ \\
\hline Maize Zea mays L. & 1.46 & 1.68 & 0.148 & 7.5 & 268 & 147 & 9.78 \\
\hline Rapeseed Brassica napus L. & 1.62 & 1.76 & 0.174 & 7.0 & 175 & 138 & 13.8 \\
\hline
\end{tabular}

Meteorological conditions during vegetation period were characterized using hydrothermal coefficient (HTK) (Lietuvos hidrometeorologijos ..., 1992). These were near optimal values for crop grows in June $(\mathrm{HTK}=1.11)$, however slight draught existed in July $(\mathrm{HTK}=0.82)$, but excessive humidity was specified in August $(\mathrm{HTK}=2.08)$ or 2 times higher than that in June.

June - August weather, compared with the multiannual means, was warm with a mean temperature $14.7{ }^{\circ} \mathrm{C}$ $20.6{ }^{\circ} \mathrm{C}$ and $17.8^{\circ} \mathrm{C}$ higher in June, July and August respectively (Figure1.). The mean temperature was as compared to by $57 \%, 69 \%$ and $65 \%$ in June, July and August as compared to the multiannual means (Figure 2). The amount of precipitation was the lowest $(49.4 \mathrm{~mm})$ in June than that in July $(52.5 \mathrm{~mm})$ and August $(111.3 \mathrm{~mm})$. Precipitation rate was observed $77 \%, 75 \%$ and $45 \%$ lower in June, July, and August, as compared to multiannual means.

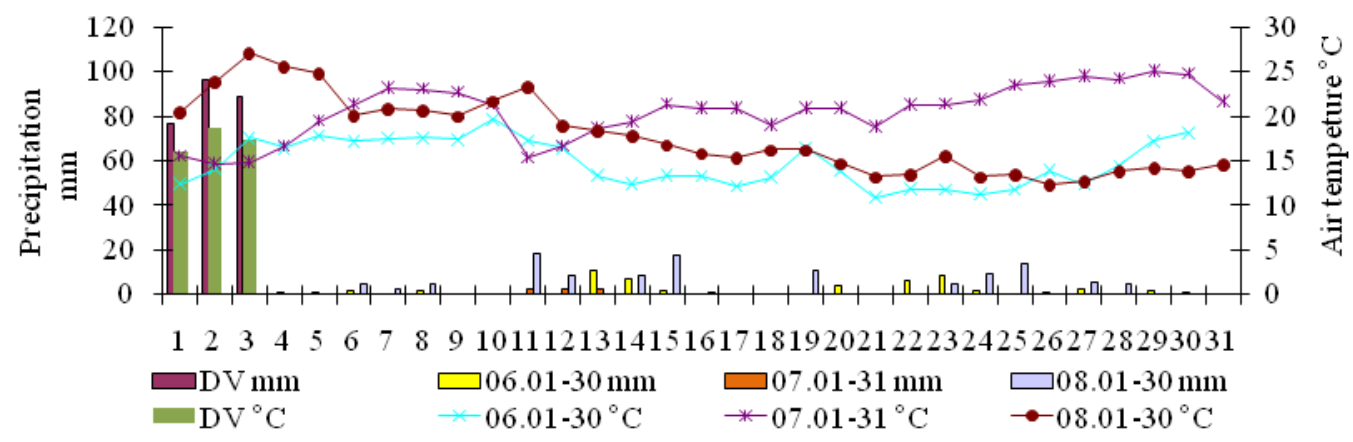

Figure 1. Meteorological conditions. DV - multiannual means

The deviation of respiration and photosynthesis assimilated $\mathrm{CO}_{2}$, leaf surface index (LAI), plant weight, net primary production (NPP) values from the values of the general plurality were estimated by standard error (mean \pm SE). For the quantitative evaluation of data, when compared two agroecosystems, the Student' t-test was used, applying analysis of variance $(\mathrm{p}<0.05)$ using STATISTICA program package. Correlation coefficient $\mathrm{r}$ between $\mathrm{CO}_{2}$ emissions 
and environmental conditions (temperature $(\mathrm{T})$, the hydrothermal coefficient (HTK) and the organic carbon concentration $\left(\mathrm{C}_{\mathrm{org}}\right.$.) ; also between photosynthesis assimilated $\mathrm{CO}_{2}$ rate and the $\mathrm{LAI}$ and crop biomass was evaluated.

\section{RESULTS AND DISCUSSION}

Regardless of agroecosystem type, the mean soil respiration $\mathrm{CO}_{2}$ was $2.085 \mu \mathrm{m}^{-2} \mathrm{~s}^{-1}$ during the vegetation season (Table 2). Though maize sowing was in the beginning of the $2^{\text {nd }}$ decade of April in 2014, or 8-12 days earlier than usual, the mean soil $\mathrm{CO}_{2}$ emission was $1.971 \mu \mathrm{mol} \mathrm{m} \mathrm{m}^{-2} \mathrm{~s}^{-1}$, or $0.228 \mu \mathrm{mol} \mathrm{m} \mathrm{m}^{-2} \mathrm{~s}^{-1}(11 \%)$ lower than in rapeseed. The highest soil $\mathrm{CO}_{2}$ emission $\left(2.963 \mu \mathrm{mol} \mathrm{m} \mathrm{m}^{-2} \mathrm{~s}^{-1}\right.$ of maize, and $2.758 \mu \mathrm{mol} \mathrm{m} \mathrm{m}^{-2} \mathrm{~s}^{-1}$ of rapeseed) was recorded in the second half of July, when the mean temperature was $20.6^{\circ} \mathrm{C}$ and $\mathrm{HTC}=0.82$ (Fig. 1). There was a strong correlation between the mean soil $\mathrm{CO}_{2}$ emissions and air temperature $\left(\mathrm{r}_{\mathrm{T}}=0.9\right)$ and $\mathrm{HTC}\left(\mathrm{r}_{\mathrm{HTK}}=0.6\right)$. Discovered dependency meets Zhang et al. (2013) findings that 70-83\% of $\mathrm{CO}_{2}$ emissions strongly depend on temperature and precipitation.

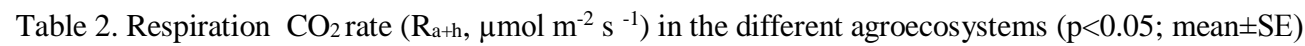

\begin{tabular}{|l|c|c|c|c|c|c|c|c|c|c|c|}
\hline 06.02. & 06.14 & 06.27 & 07.03 & 07.11 & 07.19 & 07.24 & 07.30 & 08.08 & 08.20 & 08.29 & Mean \\
\hline \multicolumn{10}{|c|}{ Maize Zea mays L. } \\
\hline 1.405 & 1.848 & 1.405 & 2.307 & 2.157 & 2.457 & 2.140 & 2.963 & 1.427 & 1.847 & 1.723 & 1.971 \\
\pm 0.15 & \pm 0.24 & \pm 0.25 & \pm 0.65 & \pm 0.48 & \pm 0.71 & \pm 0.39 & \pm 0.28 & \pm 0.51 & \pm 0.62 & \pm 0.43 & \pm 0.12 \\
\hline \multicolumn{10}{|c|}{ Rapeseed Brassica napus L. } \\
\hline 2.193 & 2.457 & 2.261 & 2.395 & 2.135 & 2.323 & 2.135 & 2.758 & 2.088 & 1.825 & 1.623 & 2.199 \\
\pm 0.46 & \pm 0.09 & \pm 0.39 & \pm 0.89 & \pm 0.67 & \pm 0.59 & \pm 0.27 & \pm 0.22 & \pm 0.35 & \pm 0.32 & \pm 0.57 & \pm 0.25 \\
\hline
\end{tabular}

The increasing trend of soil $\mathrm{CO}_{2}$ emissions was determined from July to August $(\mathrm{r}=0.8)$, and might be explained by the optimal conditions of the period for the formation of the soil microbial activity and extensive plant root growth (Reicoscky, Lindstrom, 1993). However, the mean soil $\mathrm{CO}_{2}$ emissions depended not only on different agroecosystem autotrophs or meteorological conditions, but also $\mathrm{C}_{\text {org }}$ concentrations in soil $(\mathrm{r}=0.9)$. $\mathrm{C}_{\text {org }}$ concentrations in the soil were $1.46 \%$ and $1.62 \%$ for maize and rapeseed (Table 1 ).

Even so, the photosynthesis is related to plant growth stages (Suyker et al., 2003). The assimilated $\mathrm{CO}_{2}$ rate of maize was the highest in the beginning of July $\left(17.74 \mu \mathrm{mol} \mathrm{m} \mathrm{m}^{-2}\right.$ ) at flowering stage (BBCH 40-69), and rapeseed in June $\left(14.44 \mu \mathrm{mol} \mathrm{m} \mathrm{m}^{-2} \mathrm{~s}^{-1}\right)$ at stem growth (BBCH 30-50), when crop synthesis of organic materials and LAI grow occurred intensively $\left(\mathrm{r}_{\mathrm{LAI}}=0.9\right)($ Table 3$)$.

Table 3. Assimilated $\mathrm{CO}_{2}$ (GPP), leaf surface index (LAI) raw biomass (M) at different growth stages of different agro-ecosystems $(\mathrm{p}<0.05 ;$ mean $\pm \mathrm{SE})$

\begin{tabular}{|c|c|c|c|c|c|c|c|c|c|c|c|c|}
\hline $\begin{array}{l}\text { Parameter } \\
\text { / Date }\end{array}$ & 06.02 & 06.14 & 06.27 & 07.03 & 07.11 & 07.19 & 07.24 & 07.30 & 08.08 & 08.20 & 08.29 & Mean \\
\hline \multicolumn{13}{|c|}{ Maize Zea mays L. } \\
\hline $\begin{array}{l}\text { GPP, } \\
\mu \mathrm{mol} \mathrm{m}^{-} \\
{ }^{2} \mathrm{~s}^{-1}\end{array}$ & $\begin{array}{c}6.43 \\
\pm 0.68\end{array}$ & $\begin{array}{l}10.43 \\
\pm 0.87\end{array}$ & $\begin{array}{l}12.35 \\
\pm 1.05\end{array}$ & $\begin{array}{l}14.77 \\
\pm 0.39\end{array}$ & $\begin{array}{l}18.55 \\
\pm 1.48\end{array}$ & $\begin{array}{l}16.32 \\
\pm 2.37\end{array}$ & $\begin{array}{l}17.54 \\
\pm 1.64\end{array}$ & $21.5 \pm 2.46$ & $15.71 \pm 1.26$ & $\begin{array}{l}17.61 \\
\pm 0.61\end{array}$ & $\begin{array}{l}10.69 \\
\pm 1.21\end{array}$ & $\begin{array}{l}14.71 \\
\pm 127\end{array}$ \\
\hline $\begin{array}{l}\text { LAI, } m^{2} \\
m^{-2}\end{array}$ & $\begin{array}{l}0.127 \\
\pm 0.41\end{array}$ & $\begin{array}{l}0.412 \\
\pm 0.67\end{array}$ & $\begin{array}{l}1.049 \\
\pm 0.41\end{array}$ & $\begin{array}{l}1.989 \\
\pm 0.18\end{array}$ & $\begin{array}{l}2.876 \\
\pm 0.46\end{array}$ & $\begin{array}{l}3.341 \\
\pm 0.42\end{array}$ & $\begin{array}{l}4.121 \\
\pm 0.57\end{array}$ & $4.987 \pm 0.31$ & $5.541 \pm 0.27$ & $\begin{array}{l}5.891 \\
\pm 0.87\end{array}$ & $\begin{array}{l}6.384 \\
\pm 0.53\end{array}$ & $\begin{array}{l}3.338 \\
\pm 0.46\end{array}$ \\
\hline $\mathrm{M}, \mathrm{g} \mathrm{m}^{-2}$ & $\begin{array}{l}112.9 \\
\pm 0.58 \\
\end{array}$ & $\begin{array}{l}312.5 \\
\pm 0.31 \\
\end{array}$ & $\begin{array}{c}498.68 \\
\pm 0.49 \\
\end{array}$ & $\begin{array}{l}629.87 \\
\pm 0.84 \\
\end{array}$ & $\begin{array}{c}774.63 \\
\pm 0.58 \\
\end{array}$ & $\begin{array}{c}861.24 \\
\pm 0.33 \\
\end{array}$ & $\begin{array}{c}987.43 \\
\pm 0.19 \\
\end{array}$ & $1346.01 \pm 0.57$ & $1523.21 \pm 0.64$ & $\begin{array}{l}1589.8 \\
\pm 0.98\end{array}$ & $\begin{array}{l}1604.9 \\
\pm 0.54\end{array}$ & $\begin{array}{l}931.01 \\
\pm 0.55\end{array}$ \\
\hline \multicolumn{13}{|c|}{ Rapeseed Brassica napus L. } \\
\hline $\begin{array}{l}\text { GPP, } \\
\mu \mathrm{mol} \mathrm{m}^{-} \\
{ }^{2} \mathrm{~s}^{-1}\end{array}$ & $\begin{array}{l}13.66 \\
\pm 0.79\end{array}$ & $\begin{array}{l}14.01 \\
\pm 0.47\end{array}$ & $\begin{array}{l}15.66 \\
\pm 1.09\end{array}$ & $\begin{array}{l}16.79 \\
\pm 0.57\end{array}$ & $\begin{array}{l}10.20 \\
\pm 2.64\end{array}$ & $\begin{array}{l}12.34 \\
\pm 2.53\end{array}$ & $\begin{array}{l}11.96 \\
\pm 1.18\end{array}$ & $9.87 \pm 2.23$ & $8.93 \pm 1.42$ & $\begin{array}{c}8.87 \\
\pm 1.58\end{array}$ & 0 & $\begin{array}{l}11.12 \\
\pm 1.31\end{array}$ \\
\hline $\begin{array}{l}\text { LAI, } m^{2} \\
m^{-2}\end{array}$ & $\begin{array}{l}0.187 \\
\pm 0.25\end{array}$ & $\begin{array}{l}0.347 \\
\pm 0.19\end{array}$ & $\begin{array}{l}0.762 \\
\pm 0.57\end{array}$ & $\begin{array}{l}1.157 \\
\pm 0.48\end{array}$ & $\begin{array}{l}1.876 \\
\pm 0.58\end{array}$ & $\begin{array}{l}2.697 \\
\pm 0.34\end{array}$ & $\begin{array}{l}2.957 \\
\pm 0.32\end{array}$ & $3.271 \pm 0.32$ & $3.346 \pm 0.21$ & $\begin{array}{l}3.378 \\
\pm 0.12\end{array}$ & 0 & $\begin{array}{l}1.998 \\
\pm 0.34\end{array}$ \\
\hline $\mathrm{M}, \mathrm{g} \mathrm{m}^{-2}$ & $\begin{array}{l}131.4 \\
\pm 0.34\end{array}$ & $\begin{array}{l}241.3 \\
\pm 0.5\end{array}$ & $\begin{array}{l}312.9 \\
\pm 0.61\end{array}$ & $\begin{array}{l}437.2 \\
\pm 0.54\end{array}$ & $\begin{array}{l}519.2 \\
\pm 0.15\end{array}$ & $\begin{array}{c}589.23 \\
\pm 0.68\end{array}$ & $\begin{array}{l}641.8 \\
\pm 0.91\end{array}$ & $679.9 \pm 0.54$ & $709.8 \pm 0.47$ & $\begin{array}{l}721.4 \\
\pm 0.21\end{array}$ & 0 & $\begin{array}{c}498.41 \\
\pm 0.49\end{array}$ \\
\hline
\end{tabular}

In July, the maize also reached the flowering (BBCH 50-79) and cob growth (BBCH 60-89) stages, when rapidly increased the plant biomass. Therefore, its assimilated (sequestered) $\mathrm{CO}_{2}$ increased by $63 \%$ in July as compared in June. While in mid-June maize formed only 5-8 leaves (BBCH 15-29). $\mathrm{CO}_{2}$ sequestration was higher by $45 \%$ and $17 \%$ in July respectively compared with June and August. Maize increased in biomass, due to suitable weather conditions, specifically temperature $(\mathrm{r}=0.8)$ and HTK $(\mathrm{r}=0.7)$ in July. This corresponds to Baldocch (2003) conclusion that maize is a warm climate $\mathrm{C}_{4}$-type species, for which the favorable conditions are relatively warm humid summer temperatures of 18-24 ${ }^{\circ} \mathrm{C}$. Moreover, the mean maize assimilated $\mathrm{CO}_{2}$ was $24 \%$ higher than that of the rapeseed. This difference followed plant different biological peculiarities. Maize is $\mathrm{C}_{4}$ (Berry, Bjorkman, 1980), and rapeseed $-\mathrm{C}_{3}$ photosynthetic type plants, consistently different in leaf anatomical structure and chloroplast size (Edwards, Huber, 1979). 
For the calculation $\mathrm{C}$ budget in agroecosystems, net primary production of the maize and rapeseed were estimated (Table 4) and was subjected on the $\mathrm{CO}_{2}$ assimilation rate and leaf area index. As exhibited previously, these crop indicators correlated with environmental conditions.

Table 4. Crop net primary production (NPP, $\left.\mu \mathrm{mol} \mathrm{m}^{-2} \mathrm{~s}^{-1}\right)$ in the different agroecosystems $(\mathrm{p}<0.05 ;$ mean $\pm \mathrm{SE})$

\begin{tabular}{|c|c|c|c|c|c|c|c|c|c|c|c|}
\hline 06.02 & 06.14 & 06.27 & 07.03 & 07.11 & 07.19 & 07.24 & 07.30 & 08.08 & 08.20 & 08.29 & Mean \\
\hline \multicolumn{12}{|c|}{ Zea mays $\mathrm{L}$. } \\
\hline 4.78 & 8.31 & 10.67 & 12.18 & 16.15 & 13.58 & 15.12 & 12.44 & 17.06 & 19.39 & 15.37 & 13.16 \\
\hline \pm 0.55 & \pm 0.93 & \pm 1.25 & \pm 1.27 & \pm 1.87 & \pm 2.87 & \pm 1.74 & \pm 1.56 & \pm 2.12 & \pm 0.87 & \pm 1.25 & \pm 1.48 \\
\hline \multicolumn{12}{|c|}{ Brassica napus L. } \\
\hline $\begin{array}{l}11.17 \\
\pm 0.94\end{array}$ & $\begin{array}{l}11.20 \\
\pm 0.87\end{array}$ & $\begin{array}{l}13.07 \\
\pm 1.47\end{array}$ & $\begin{array}{l}14.01 \\
\pm 1.74\end{array}$ & $\begin{array}{c}7.71 \\
\pm 1.58\end{array}$ & $\begin{array}{c}9.69 \\
\pm 2.43\end{array}$ & $\begin{array}{c}9.48 \\
\pm 1.58\end{array}$ & $\begin{array}{c}6.79 \\
\pm 1.52\end{array}$ & $\begin{array}{c}6.47 \\
\pm 1.57\end{array}$ & $\begin{array}{l}6.412 \\
\pm 1.12\end{array}$ & 0 & $\begin{array}{c}8.72 \\
\pm 1.35\end{array}$ \\
\hline
\end{tabular}

NPP express the sequestered carbon rate in biomass during vegetation period. NPP of maize was estimated by $31 \%$ and 91 igher than that of rapeseed in July and August, respectively. The mean C budget (mean NPP) was $15.54 \mathrm{t}$ $\mathrm{ha}^{-1}$ in maize and $10.30 \mathrm{t} \mathrm{ha}^{-1}$ in rapeseed agroecosystem. The maize mean NPP was assessed by $66 \%$ higher than that of rapeseed during vegetation period. That indicated that maize take more $\mathrm{CO}_{2}$ from the atmosphere, assimilated and accumulated in biomass than that in rapeseed. Subsequently, the maize $\mathrm{C}$ sequestration potential is higher than that of rapeseed. Therefore, targeting to increase $\mathrm{C}$ sequestration and reduce $\mathrm{CO}_{2}$ emissions in the agrarian sector, and thus to mitigate its contribution to climate change, as well as steering to keep the environmental sustainability, the maize areas should be increased. However, the farm economic direction and special needs must be taken into account. Agroecosystems were characterized by seasonal C flux changes during the autotroph vegetation season (Figure 2). Sequestered $\mathrm{C}$ rate in biomass depended on the crop species and environmental conditions. A large proportion of assimilated $\mathrm{C}$ of $70-80 \%$ was sequestered in the yield biomass, and plant residues, and thus mitigated $\mathrm{C}$ pool in atmosphere. Moreover, following to Hollinger et al. (2005), this C ratio sequestered in plant residues (roots etc.) remained deposited in the soil increasing its fertility.
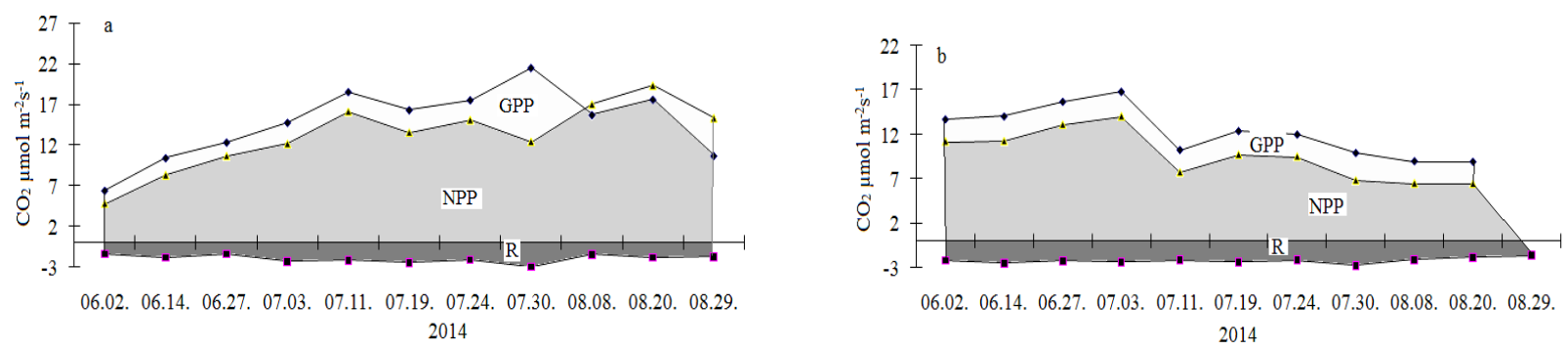

Figure 2. Photosynthetic and respirational $\mathrm{CO}_{2}$ flux intensity in maize (a) and rapeseed (b) agroecosystems

Though different $\mathrm{C}$ content (NPP) was captured from atmosphere and accumulated in biomass of the studied agroecosystems, however following to Smith et al. (2008), soil C pool there can increase up to $89 \%$ or might became stabilized by the means of changing crop rotation system. As Ogle et al. (2005) documented, if the annual crop rotation species are changed, so there is no long-term accumulation of above ground biomass due to harvested and removed production. Therefore the carbon sequestration in biomass and in the soil has important potential to capture $\mathrm{CO}_{2}$ from the atmosphere and store them for longer periods by altering the current flux rates through improved crop rotation management.

\section{CONCLUSION}

The field study of $\mathrm{C}$ budget of both maize and rapeseed found that soil respiration $\mathrm{CO}_{2}$ emission of maize was $11 \%$ lower than that of rapeseed. The maximum measured soil $\mathrm{CO}_{2}$ emission was in July at maize flowering and cob growth (BBCH 50-79) and rapeseed stem elongation - flowering (BBCH 40-69) stages.

A strong correlation between the mean $\mathrm{CO}_{2}$ emission and soil temperature and $\mathrm{HTC}$ was revealed. Consequently, NPP and GPP vary depending on season conditions (precipitation and temperature) of assessed crops. Photosynthetically assimilated $\mathrm{CO}_{2}$ correlated with crop growth stages, leaf surface index $(\mathrm{r}=0.9)$ and biomass rate $(\mathrm{r}=0.8)$. In addition, the soil $\mathrm{CO}_{2}$ flux from agroecosystems can contribute significantly to the increase in the NPP. Maize and spring rape sequestered more $\mathrm{CO}_{2}$ from the environment than emitted. Nonetheless, due to different biological peculiarities, the mean $\mathrm{C}$ budget and thus $\mathrm{C}$ sequestration potential of maize was $34 \%$ higher than that of rapeseed.

\section{REFERENCES}

1. Amthor, J. S., Baldocchi, D. D. 2001.Terrestrial higher plant respiration and net primary production. In: Terrestrial Global Productivity, edited by Roy, J., Saugier, B., Mooney, H. A. Academic Press, San Diego. http://dx.doi.org/10.1016/B978$\underline{012505290-0 / 50004-1}$ 
2. Anthony, K. R., Connolly, S. R.. 2004. Environmental limits to growth: Physiological niche boundaries of corals along turbiditylight gradients. Oecologia, Vol. 141, Iss. 3, pp. 373-384.

3. Aertsens, J., De Nocker, L., Gobin. A. 2013. Valuing the carbon sequestration potential for European agriculture. Land Use Policy, vol. 31, pp. 584- 594. http://dx.doi.org/10.1016/j.landusepol.2012.09.003

4. Baldocchi, D. D. 2003. Assessing the eddy covariance technique for evaluating carbon dioxide exchange rates of ecosystems: Past, present and future. Global Change Biology, Vol. 9, Iss. 4, pp. 479-492. http://dx.doi.org/10.1046/j.1365-2486.2003.00629.x

5. Baležentienè, L., Bleizgys, R. 2011. Short-term inventory of GHG fluxes in semi natural and anthropogenized grassland in the Lithuania. Polish Journal of Environmental Studies, Vol. 20, No. 2, pp. 255-262.

6. Baležentienè, L., Kusta, A. 2012. Reducing Greenhouse Gas Emission sin Grassland Ecosystems of the Central Lithuania: MultiCriteria Evaluationon a Basis of the ARAS Method. The Scientific World Journal, Vol. 20, pp. 1-11. http://dx.doi.org/10.1100/2012/908384

7. Berry, J. A., Bjorkman, O. 1980. Photosynthetic response and adaptation to temperature in higher plants. Annals Review of Plant Physiology, Vol. 31, pp. 491-543. http://dx.doi.org/10.1146/annurev.pp.31.060180.002423

8. Edwards, G. E., Huber, S. C. 1979. In: Gibbs, M., Latzko, E. (eds), Photosynthesis 11. Springer-Verlag, Berlin, pp. $102-112$.

9. Hollinger, S. E., Bernacchi, C. J., Meyers, T. P. 2005. Carbon budget of mature no-till ecosystem in North Central Region of the United States. Agricultural and Forest Meteorology, Vol. 130, Iss. 1-2, pp. 59-69. http://dx.doi.org/10.1016/j.agrformet.2005.01.005

10. IPCC. 2007. Special report on land use, land use change, and forestry. Cambridge University Press. Cambridge.

11. Liang, S., Fang, H. 2004. Applications of multi angle measurements. In: Reflection properties of vegetation canopy and soil with a BRDF data base, ed. by M. Scholarmark, Wissenschaft und Technik Verlag, pp.243-258.

12. History of Lithuanian hydrometeorology service [Lietuvos hidrometeorologijos tarnybos istorija]. 1992. 15 t., LHMT, Vilnius. (In Lithuanian)

13. Meier, U. 2001. Growth stages of mono-and dicotyledonous plants: BBCH Monograph. Federal Biological Research Centre for Agriculture and Forestry.

14. Ogle, S. M., F. J. Breidt, Paustian K. 2005. Agricultural management impacts on soil organic carbon storage under moist and dry climatic conditions of temperate and tropical regions. Biogeochemistry, Vol. 72, Iss. 1, pp. 87-121. http://dx.doi.org/10.1007/s10533-004-0360-2

15. Robert, M., Saugier, B. 2003. Contribution of terrestrial ecosystems to carbon sequestration. Comptes Rendus Geoscience, Vol. 335, Iss. 6-7, pp. 577-595. http://dx.doi.org/10.1016/S1631-0713(03)00094-4

16. Root, T. L., Price, J. T., Hall, K. R., Schneider, S. H., Rosenzweig, C. J., Pounds, A. 2003. Fingerprints of global warming on wild animals and plants. Nature, Vol. 421, pp. 57-60. http://dx.doi.org/10.1038/nature01333

17. Saito, K., Linquist, B., Keobualapha, B., Shiraiwa, T., Horie, T. 2006. Farmers' knowledge of soils in relation to cropping practices: A case study of farmers in upland rice based slashand-burn systems of northern Laos. Geoderma, Vol. 136, Iss. 12, pp. 64-74. http://dx.doi.org/10.1016/j.geoderma.2006.02.003

18. Smith, P., Martino, D., Cai, Z., Gwary, D., Janzen, H., Kumar, P., McCarl, B., Ogle, S., O'Mara, F., Rice, C., Scholes, B., Sirotenko, O., Howden, M., McAllister, T., Pan, G., Romanenkov, V., Schneider, U., Towprayoon, S., Wattenbach, M., Smith, J., 2008. Greenhouse gas mitigation in agriculture. Philosophical Transaction of The Royal Soceity B: Biologoical Science, Vol. 363, Iss. 1492, pp. 789-813. http://dx.doi.org/10.1098/rstb.2007.2184

19. Schimel, D., Alves, D., Enting, I., Heimann, M., Joos, F., Raynaud D., Wigley, T. 2002. $\mathrm{CO}_{2}$ and the carbon cycle. In: Climate Change 2001: The Science of Climate Change: Contribution of WGI to the Second Assessment Report of the IPCC, edited by J.T. Houghton et al., Cambridge University Press, New York. pp. 65-86.

20. Smith, P. 2008. Land use change and soil organic carbon dynamics. Nutrient Cycle Agroecosystems, Vol. 81, Iss. 2, pp. 169-78. http://dx.doi.org/10.1007/s10705-007-9138-y

21. Suyker A. E., Verma S. B., and Burba G. G. 2003. Interannual variability in net $\mathrm{CO} 2$ exchange of a native tallgrass prairie. Global Change Biology, Vol. 9, Iss. 2, pp. 1-11. http://dx.doi.org/10.1046/j.1365-2486.2003.00567.x

22. Weisskopf, P., Reiser, R. Rek, J. 2010. Effect of different compaction impacts and varying subsequent management practices on soil structure, air regime and microbiological parameters. Soil Tillage Response, Vol. 111, Iss. 1, pp. 65-74. http://dx.doi.org/10.1016/j.still.2010.08.007

23. Zhang, Z. B., Peng, X., Wang, L. L., Zhao, Q. G., Lin, H. 2013. Temporal changes in shrinkage behavior of two paddy soils under alternative flooding and drying cycles and its consequence on percolation. Geoderma, Vol. 192, pp. 12-20. http://dx.doi.org/10.1016/j.geoderma.2012.08.009 